\title{
F-Box/WD Repeat-Containing Protein 1A
}

National Cancer Institute

\section{Source}

National Cancer Institute. F-Box/WD Repeat-Containing Protein 1A. NCI Thesaurus. Code C96369.

F-box/WD repeat-containing protein $1 \mathrm{~A}(605 \mathrm{aa}, \sim 69 \mathrm{kDa}$ ) is encoded by the human BT RC gene. This protein plays a role in the binding of ubiquitin ligase substrates. 